\title{
The Phycosiphon record in the Ladrilleros-Juanchaco section (Miocene, Colombian Pacific): palaeoecological implications
}

\author{
Sergio A. CELIS ${ }^{I^{*}}$, Francisco J. RODRÍGUEZ-TOVAR ${ }^{2} \&$ Andrés PARDO-TRUJILLO ${ }^{l}$
}
${ }^{1}$ Grupo de Investigaciones en Estratigrafía y Vulcanología-GIEV, Instituto de Investigaciones en Estratigrafía, Departamento de Ciencias Geológicas, Universidad de Caldas, Calle 65 № 26 - 10, Manizales, 275, Colombia; sergio.celis@ucaldas.edu.co; andres.pardo@ucaldas.edu.co
${ }^{2}$ Departamento de Estratigrafía y Paleontología, Universidad de Granada, Avda. Severo Ochoa s/n, 18002 Granada, Spain; fjrtovar@ugr.es
* Corresponding author

Celis, S.A., Rodríguez-Tovar, F.J. \& Pardo-Trujillo, A. 2018. The Phycosiphon record in the Ladrilleros-Juanchaco section (Miocene, Colombian Pacific): palaeoecological implications. [El registro de Phycosiphon en la sección Ladrilleros-Juanchasco (Mioceno, Pacífico de Colombia): implicaciones paleoecologicas]. Spanish Journal of Palaeontology, 33 (2), $277-288$.

Manuscript received 20 December 2017

Manuscript accepted 29 June 2018

(C) Sociedad Española de Paleontología ISSN 2255-0550

\section{ABSTRACT}

Miocene rocks of the Ladrilleros-Juanchaco section, located on the NW margin of South America, contain a high diverse and abundant trace fossil assemblage. The relative abundance of Phycosiphon, together with its morphological variations, provides new insights into the environmental conditions. Detailed outcrop stratigraphic, ichnological, and geochemical analyses carried out in the section focused on the trace fossil assemblages (distribution, relative abundance), ichnofabric index, and, especially, in the general ichnological features of Phycosiphon. In addition, the detailed photographic documentation and the use of the digital image treatment technique facilitate the precise study of particular ichnological properties.

Based on the stratigraphic analysis of the section, together with the abundance, size and distribution of the specimens of Phycosiphon, as well as the analysis of total organic carbon, the record of Phycosiphon is proved as related to the food content in the sediment, and then as a proxy in the study of ancient environments.

Keywords: Ichnology, Phycosiphon, Miocene, LadrillerosJuanchaco section, Colombia, palaeoecological and depositional conditions.

\section{RESUMEN}

La sección Ladrilleros-Juanchaco, de edad Mioceno, localizada en el margen NW de Suramérica, presenta alta diversidad $\mathrm{y}$ abundancia de icnofósiles. La relativa abundancia de Phycosiphon, junto con sus variaciones morfológicas abre una nueva línea de interés en la investigación paleoambiental. El detallado análisis estratigráfico e icnológico que se realizó en la sección, se centró en el estudio de las asociaciones de trazas fósiles (distribución, abundancia relativa) e índice de icnofábricas, y, especialmente, en las características icnológicas generales de Phycosiphon. Además, el registro fotográfico detallado y el uso de la técnica de tratamiento de imágenes facilitaron precisar algunas características icnológicas.

Sobre la base del estudio estratigráfico de la sección, junto con la abundancia, tamaño y distribución de los especímenes de Phycosiphon, así como el análisis de carbono orgánico total, se ha demostrado la relación entre el registro de Phycosiphon y el contenido de nutrientes en el sedimento, y, por tanto, su interés como indicador en estudios paleoambientales.

Palabras claves: icnología, Phycosiphon, Mioceno, sección Ladrilleros-Juanchaco, Colombia, condiciones paleoecológicas y deposicionales. 


\section{INTRODUCTION}

In tropical Eastern South America, Miocene strata have been increasingly studied in recent years, because their location retains valuable information about the geological history not only local, but also regional and possibly global by processes related to the uplift of the Andes, and the formation of the Panama Isthmus (e.g., Duque-Caro, 1990a, 1990b; Coates et al., 2004; Farris et al., 2011; Montes et al., 2012; 2015; Villagómez \& Spikings, 2013; Echeverri et al., 2015; Vallejo et al., 2016; Plata et al., 2018; Duque-Herrera et al., 2018).

The Ladrilleros-Juanchaco section, located at the SW margin of Colombia (NW of South America) (Fig. 1), becomes of special interest to interpret the Colombian Pacific area, recently dated as Miocene (BurdigalianTortonian) in age (Vallejo et al., 2016; Plata et al., 2018). Ichnological and stratigraphic analyses reveal hemipelagic sedimentation constituted by pelagic material, lowdensity turbidites, bottom currents, together with minor contribution of continental material through hyperpicnal flows (Celis, 2016). However, the sedimentological characterization does not provide information about the ecological and depositional factors.

In the last years, ichnological studies have been revealed as a tool in sedimentary research, improving characterization of deep marine environments (RodríguezTovar \& Uchman, 2004a, 2004b, 2006, 2010, 2017; Rodríguez-Tovar et al., 2009a, 2009b, 2011a, 2011b, 2013, 2014, 2016; Monaco et al., 2012; Uchman \& Wetzel, 2012; Wetzel \& Uchman, 2012; Callow et al., 2014; Bayet-Goll et al., 2015, 2016). In combination with the analysis of the ichnological assemblage, some distinct ichnotaxa acquire a special relevance due to their particular characteristics and their relation with specific environmental conditions. This is the case of Phycosiphon, frequently associated with abundant benthic food and sufficient oxygenation (Wetzel \& Uchman, 2001; Pervesler \& Uchman, 2007; Wetzel, 2010; Rodríguez-Tovar et al., 2014). The high abundance of this ichnogenus in the studied section and its morphological variability provide new information about the palaeoenvironmental conditions. This is even more significant and increases the validity of the results obtained, if other abiotic proxies are considered in addition. For instance, total organic carbon (TOC) values can be very useful because they are closely related to the availability of benthic food in the substrate.

The aim of the present study is the integration of ichnological observations with special attention to the trace fossil Phycosiphon, as well as TOC data and the stratigraphic information, in order to understand and interpret the environmental conditions during deposition of the sediments exposed in the Ladrilleros-Juanchaco section in more detail.

\section{GEOLOGICAL SETTING AND STRATIGRAPHY}

The geological configuration of Colombia exhibits a complex mixture of allochthonous blocks, bounded by tectonic structures (faults systems) that cross the country in north-south direction, parallel to the current subduction zone between the Nazca and South American Plates. The combined activity of these mechanisms (subduction and thrusting) has given rise to the division of the Colombian Andes into three mountain ranges, Eastern, Central and Western. The Western Cordillera basement is composed by oceanic terranes that became attached to the NW of Colombia during the Late Cretaceous (Spikings et al., 2001, 2010). These allochthonous blocks are constituted by igneous (mafic) and sedimentary rocks formed in oceanic plateau and/or island arc environments (Villagómez et al., 2011). To the west of the Western Cordillera there is the Colombian Pacific area which is formed by two sedimentary basins, the Tumaco and Choco Basins (Barrero et al., 2007; Suárez-Rodríguez, 2007). The Choco Basin is subdivided by the Istmina Condoto High into the Atrato and San Juan Sub-basins (Cediel et al., 2010). The JuanchacoLadrilleros section is located in the San Juan Sub-basin, which has a surface area of $10,500 \mathrm{~km}^{2}$ (Suárez-Rodríguez, 2007). Numerous stratigraphic studies have been carried out in the San Juan Sub-basin. They focus on local aspects and mainly address the so-called Istmina Condoto High, and upper valley of the San Juan River (Rojas, 1967; BGR - Ingeominas, 1989; Figueroa \& Nuñez, 1990; Dunia Consultores Ltda, 2006; Bedoya et al., 2009; Gallego, 2017). These studies reveal that the Paleocene to Pliocene sediment succession consists of five lithostratigraphic units: Iró Formation (Eocene), Istmina Formation (lower Miocene), Conglomerados de la Mojarra Formation (lower Miocene), Condoto Formation (middle Miocene) and Raposo/Mayorquín Formation (Pliocene) (Bedoya et al., 2009; Cediel et al., 2010). The section addressed in the present study was investigated by Montoya (2003), and for the first time the informal name of Sedimentitas de Ladrilleros is introduced and the overlaying younger Mayorquín Formation was recognized as such.

The Ladrilleros-Juanchaco section is located west of the Western Cordillera in the San Juan Sub-basin in southwestern Colombia $\left(3^{\circ} 57^{\prime} \mathrm{N}-77^{\circ} 22^{\prime} \mathrm{W}\right.$ and $3^{\circ} 55^{\prime} \mathrm{N}$ $77^{\circ} 21^{\prime} \mathrm{W}$ ) between the towns of Ladrilleros and Juanchaco, $40 \mathrm{~km} \mathrm{NW}$ of the Buenaventura city (Fig. 1) (Duque-Caro, 1991; Barrero et al., 2007). It belongs to the sedimentary fill of the basin at the Colombian Pacific. The section is exposed almost continuously along coastal cliffs, where siliciclastic strata of approximately $680 \mathrm{~m}$ of thickness are outcropping (ANH-U Caldas, 2011; Celis, 2016).

Biostratigraphic and biochronologic studies based on calcareous nannofossils, planktonic foraminifera and diatoms reveal seventeen astronomically and standard 

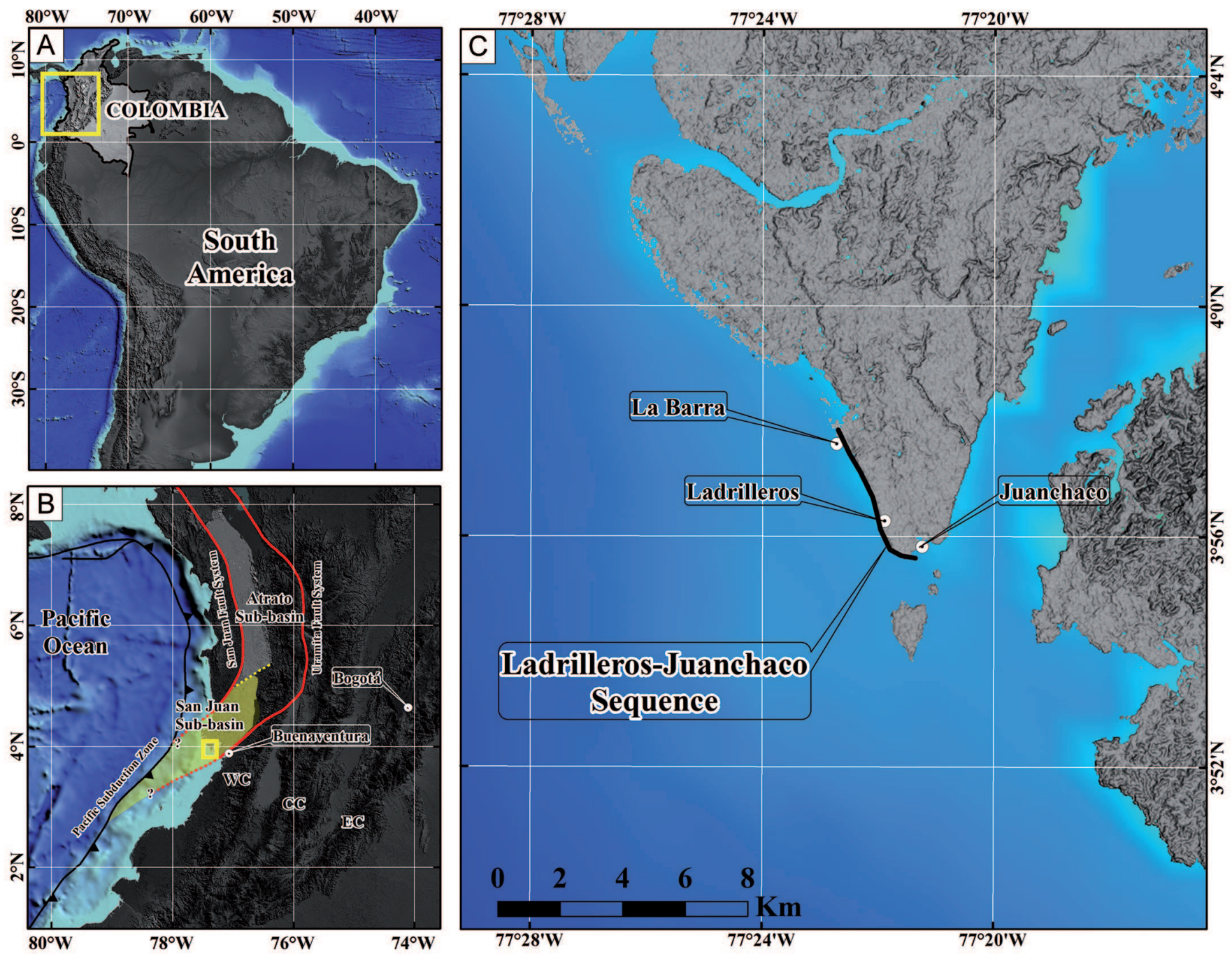

$7^{\circ} 28^{\prime} \mathrm{W}$

$\mathbf{7 7}^{\circ} \mathbf{2 4} \mathrm{W}$

Figure 1. a) Location map of South America. b) Regional tectonic configuration of the study area. WC: Western Cordillera; CC: Central Cordillera; EC: Eastern Cordillera. (Basin limits from Barrero et al., 2007; red lines: faults from Cediel et al., 2010). c) Location map of Ladrilleros-Juanchaco section.

calcareous microfossil calibrated biohorizons as well as two tropical diatom biozones (Vallejo et al., 2016; Plata et al., 2018). Based on stratigraphic data a chronologic framework was established between 16.27 and $10.79 \mathrm{Ma}$ (BurdigalianTortonian) (Vallejo et al., 2016; Plata et al., 2018).

\section{MATERIAL AND METHODS}

The outcrop (685 m-thick) was studied in detail at bedby-bed scale, in particular with respect to ichnological aspects, focusing on assemblage, distribution, and relative abundance of trace fossils as well as on bioturbation index (Taylor \& Goldring, 1993). Special attention was paid to Phycosiphon burrows, including their relationships to lithology and sedimentary structures, as well as to the diameter of the traces, the pattern of distribution, and abundance. The abundance of Phycosiphon in the beds was semi-quantitatively considered: without Phycosiphon traces ( $0 \%)$, low abundance (1-30\%), middle abundance (30-60\%), high abundance $(60-90 \%)$, very high abundance $(90-100 \%)$.

A photographic documentation was taken along the succession to complete the description in the laboratory. Subsequently, the treatment of the images in computer was conducted using several digital image techniques to enhance trace fossil visibility following previous methodologies (Dorador \& Rodríguez-Tovar, 2014a, 2014b, 2018; Rodríguez-Tovar \& Dorador, 2015).

Whole-rock analyses of TOC were carried out on 60 beds, with a sampling interval of around $10 \mathrm{~m}$, showing a variable abundance of Phycosiphon. These analyses were performed in the laboratories of Universidad Nacional de Colombia - Medellín, and GMAS LTDA, Colombia. 


\section{RESULTS}

\subsection{Lithological features}

The $685 \mathrm{~m}$ thick hemipelagites constituting the LadrillerosJuanchaco section are dominated by mudrocks interlayered with sandstones beds less than $1 \mathrm{~m}$ thick (Figs 2-3). The contacts between beds are mostly planar, and rarely irregular or gradational. Most of the mudrock beds are heavily bioturbated and only occasionally laminated. These beds are dark gray, grayish black or light gray colored. Woody fragments and mollusks were observed in some intervals.
The sandstones are very fine to very coarse grained, while sorting within each layer varies. Sphericity and roundness of grains vary considerably. Sandstone beds exhibit normal and inverse grading, massive structure, parallel lamination, crossbedding, and, in some cases, synsedimentary deformation structures such as slumps and convolute bedding. Throughout the section microfossils are abundant, such as calcareous nannofossils, foraminifera (benthic and planktonic), pollen, diatoms and dinoflagellates (ANH-Universidad de Caldas, 2011; Plata, 2012; Trejos, 2012; Vallejo, 2012; Correa, 2015; Hernández-Rendón, 2015; Celis, 2016; Vallejo et al., 2016; Garzón, 2017; Plata et al., 2018).
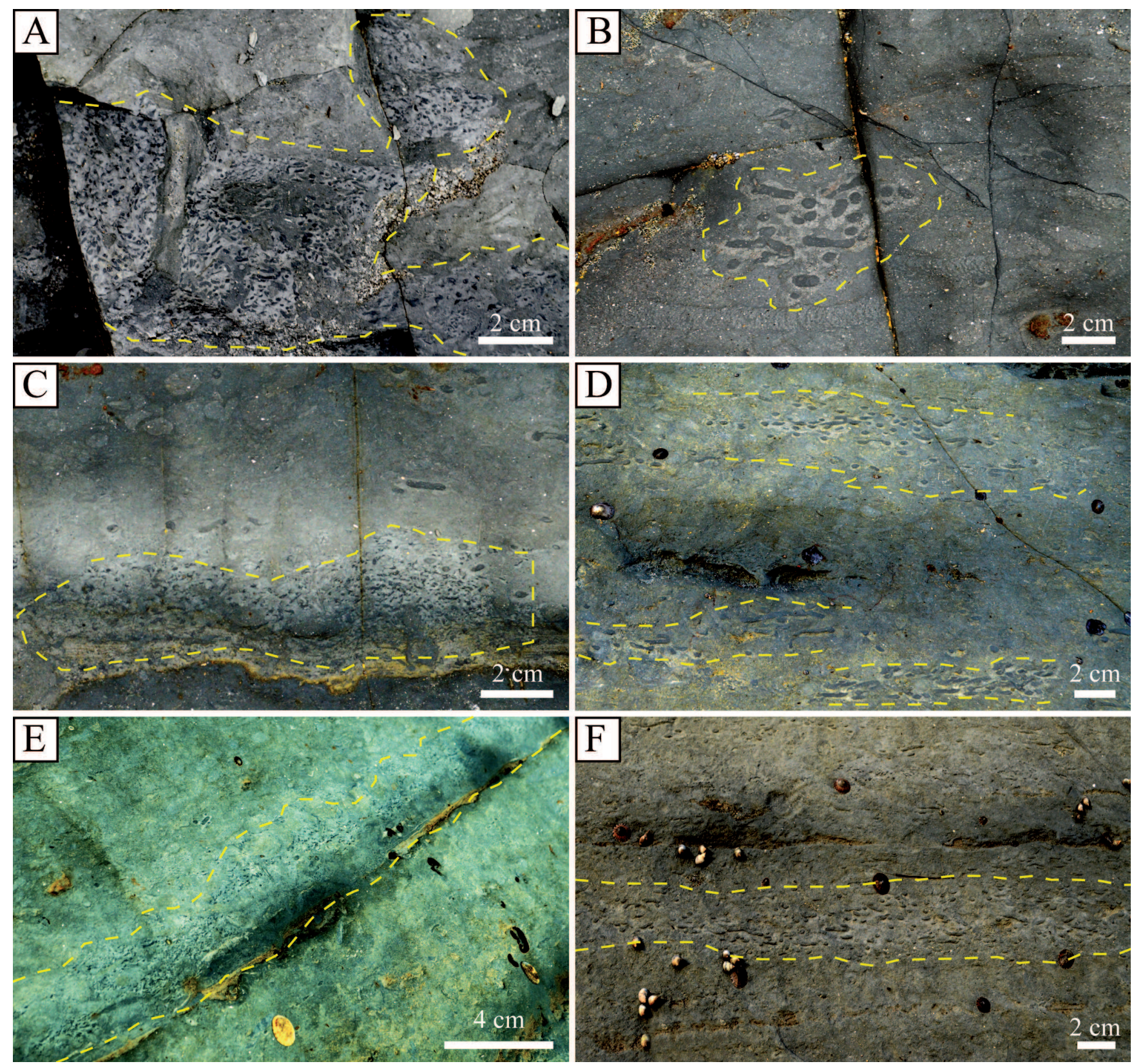

Figure 2. Distribution patterns of Phycosiphon structures in the Ladrilleros-Juanchaco section. a-b) Patchy arrangement of small (a) and large (b) Phycosiphon. c-d) Beds partly occupied by small (c) and large (d) Phycosiphon. e-f) Layers arrangement of small (e) and large (f) Phycosiphon. 


\subsection{Ichnology}

The studied section contains highly diverse and abundant trace fossils consisting of pre-depositional (Cladichnus, Cosmorhaphe, Glockerichnus, Gyrophyllites, Helminthopsis, Lorenzinia, Paleodictyon, Punctorhaphe, Spirorhaphe, and Stelloglyphus) and post-depositional traces (?Asterosoma, Chondrites, Halopoa, Nereites, Ophiomorpha, Palaeophycus, Phycodes, Phycosiphon, Phymatoderma, Planolites, Rosselia, Scolicia, Spongeliomorpha, Taenidium, Teichichnus, Thalassinoides, as well as Zoophycos). This trace fossil association is typical of the Nereites and Zoophycos ichnofacies, with a variable occurrence throughout the studied section: Nereites ichnofacies (0-59 m), Zoophycos ichnofacies (67-300 m), Nereites ichnofacies (300-360 m), Zoophycos ichnofacies (360-492 m), and impoverished Zoophycos ichnofacies (492-685 m) (Celis, 2016) (Fig. 3). Impoverished Zoophycos ichnofacies is characterized by dominance of Chondrites, Phycodes, and Phycosiphon, together with Nereites, Ophiomorpha, Palaeophycus, Phymatoderma, Planolites, Scolicia, Spirohaphe, Stelloglyphus, Taenidium, Thalassinoides, and Zoophycos. Occasionally, some graphoglyptids (i.e., Spirorhaphe and Stelloglyphus) are observed.

\subsection{Phycosiphon at the Ladrilleros-Juanchaco sequence}

Phycosiphon is present at abundance and in different spatial arrangement throughout the $685 \mathrm{~m}$-thick section. It preferably occurs in mudrock.

Phycosiphon traces appear in cross-sections, and longitudinal sections as cylindrical dark cores of varying size enveloped by a light halo around the dark tubes. Often sinuous forms or pairs of black spots surrounded by the lighter mantle are seen. The local presence of a spreiten, the outer halo and the pronounced curvatures are fundamental in the diagnosis of the ichnogenus Phycosiphon (Wetzel \& Bromley, 1994; Uchman, 1998). In section, small and extensive branched forms having narrow lobes with connections (spreiten) or U-shaped structures forming meandriform complexes are seen, while all of them show a light halo and a dark central part parallel or oblique to the stratification.

According to the size of Phycosiphon, two classes are differentiated: a) small traces having in maximum 0.3 to $0.5 \mathrm{~cm}$ length, $0.1 \mathrm{~cm}$ width, and marginal tubes $0.02 \mathrm{~cm}$ in diameter; and b) large forms with length of individual spreiten of up to $2 \mathrm{~cm}$ and $0.4 \mathrm{~cm}$ width, and marginal tubes having up to $0.1 \mathrm{~cm}$ diameter (Fig. 2). The small forms dominate throughout the section.

Detailed analysis reveals variable distribution patterns into the beds throughout the section, with differentiation of
3 different arrangements: a) patches: Phycosiphon is sparse and randomly distributed, exhibits variable orientation, and small forms are more scattered than large ones (Figs 2a-b, 3); b) horizons: Phycosiphon burrows are concentrated discontinuously in intervals less than $1 \mathrm{~m}$ thick and parallel to stratification; small traces dominate over large ones (Figs 2c-d, 3); and c) layers: Phycosiphon are densely packed in intervals parallel to the stratification with a lateral continuity exceeding $1 \mathrm{~m}$. Occurrence in patches is most frequent, while occurrence in layers is mainly observed in the intervals 245-270 $\mathrm{m}$ and 500-540 $\mathrm{m}$ where small Phycosiphon are present (Figs 2e, 3), and at the top of the section where large forms occur (Figs 2f, 3).

The abundance of Phycosiphon shows pronounced variations within the entire section (Fig. 3), being low (1$30 \%$ ) in the intervals $0-59 \mathrm{~m}$ and $300-360 \mathrm{~m}$, and high (60$90 \%)$ and very high (90-100\%) at the top of the section between 492 and $685 \mathrm{~m}$. Middle abundance (30-60\%) is observed in the intervals $67-300 \mathrm{~m}$ and $360-492 \mathrm{~m}$. Particularly, in the interval 239-268 $\mathrm{m}$, very high values of Phycosiphon abundance are presented.

\subsection{Total organic carbon}

Total organic carbon varies between 0.15 wt $\%$ and 0.80 wt \%. TOC values within the studied section show two well-differentiated intervals with minor fluctuations inside (Fig. 3). From 0 to $442 \mathrm{~m}$, the average of TOC values fluctuate between $0.2 \mathrm{wt} \%$ and $0.45 \mathrm{wt} \%$ with some peaks reaching up to $0.80 \mathrm{wt} \%$ in the interval of $237-267 \mathrm{~m}$. From 462 to $685 \mathrm{~m}$, the TOC values generally increase, ranging between $0.36 \mathrm{wt} \%$ and $0.57 \mathrm{wt} \%$ and showing a maximum of $0.65 \mathrm{wt} \%$ in the interval of $635-648 \mathrm{~m}$.

\section{INTERPRETATION AND DISCUSSION}

The behavior of the trace makers and, therefore, the biogenic structures they produce, are strongly influenced by environmental conditions. Consequently, bioturbational structures are useful as tool to decipher environmental parameters at the time of sedimentation, such as, benthic food content, temperature, salinity, oxygenation, hydraulic energy, and sedimentation rate, among others. (Uchman, 1991, 1992; Buatois \& López-Angriman, 1992; Netto \& Rossetti, 2003; Netto et al., 2009; Buatois \& Mángano, 2011; Buatois et al., 2011; Knaust \& Bromley, 2012). To evaluate the environmental conditions in the studied section occurrence of Phycosiphon is compared with already published findings.

The producer of Phycosiphon is especially sensitive to sediment grain size, mainly registered in mud to fine sand (Ekdale \& Lewis, 1991, in reference to Anconichnus). 


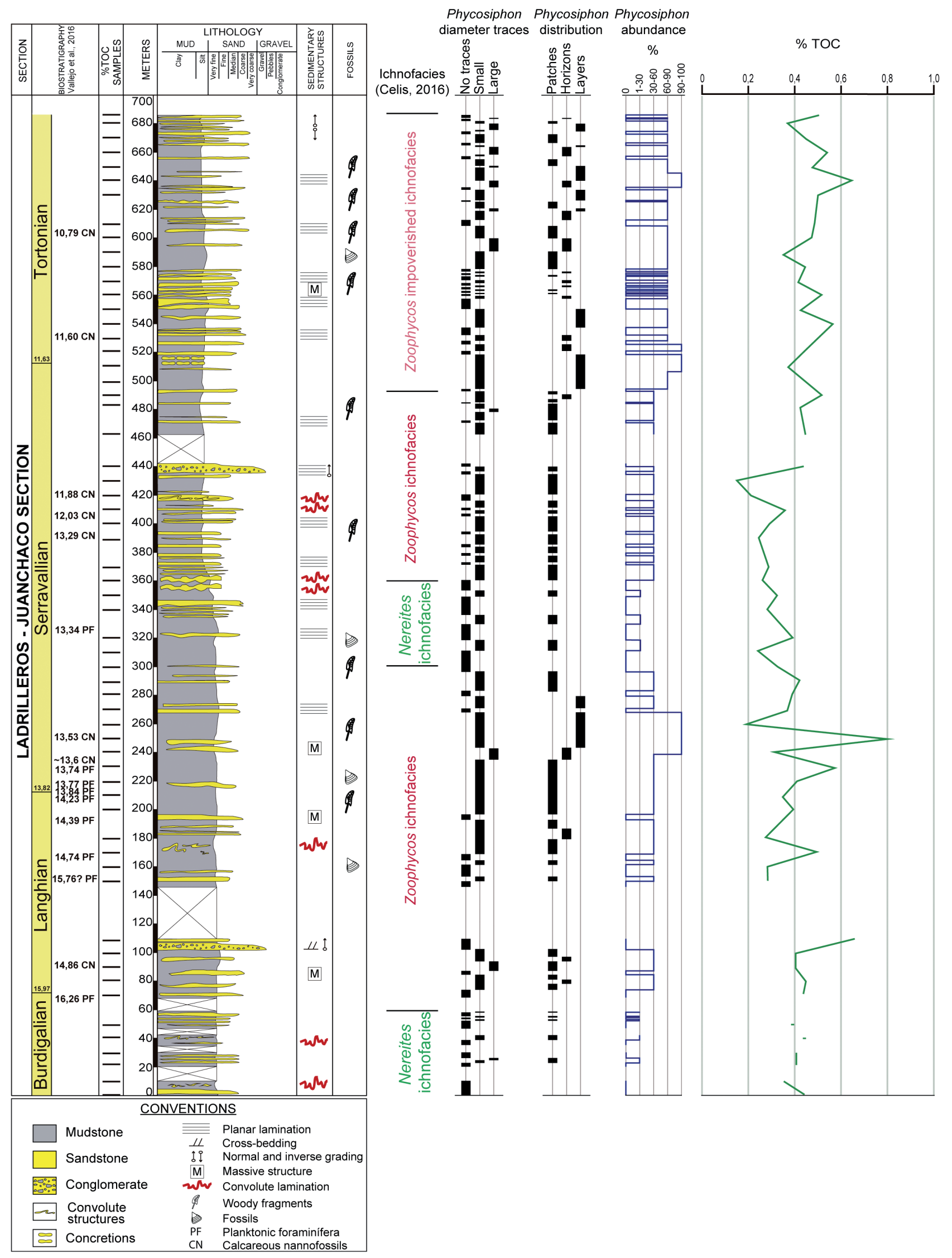

Figure 3. Graph summarizing the results: lithological column of the Ladrilleros-Juanchaco section, including data on grain size and sedimentary structures, fossils, ichnofacies (Celis, 2016), information on Phycosiphon (diameter, distribution and abundance), and stratigraphic distribution of the Total Organic Carbon (TOC) data. 
The trace is considered a pascichial/fodinichnial structure (Ekdale \& Masson, 1988; Wetzel \& Bromley, 1994); the organism selectively ingests the clay material of the sediment leaving a continuous fecal chain rich in clay in the center surrounded by a halo of sorted-out sand. The producer is usually considered as an opportunistic organism, at different tiers depths up to $15 \mathrm{~cm}$ below the sediment-water interface, in an extent range of bathymetric conditions from shallow marine to bathyal and even abyssal depths (Wetzel \& Balson, 1992; Wetzel \& Bromley, 1994; Wetzel \& Uchman, 2001). Occasionally an equilibrium population strategy has been suggested (Wetzel, 2010). The trace maker of Phycosiphon has not yet been recognized (Wetzel, 2008), but the organism producing phycosiphoniform burrows are supposedly vermiform (Wetzel \& Bromley, 1994; Bednarz \& McIlroy, 2009). It generates a series of feeding enclosing structures, lateral to the marginal tube (based on $\mathrm{Fu}, 1991$; Goldring et al., 1991; Wetzel \& Bromley, 1994; Uchman, 1995, 1999; Bromley, 1996; Seilacher, 2007; Wetzel, 2010). However, there are doubts about the behavior of the producer, its opportunistic nature or the limiting palaeoecological factors that determine its distribution, abundance and morphological features.

Phycosiphon occurs within the Ladrilleros-Juanchaco section almost continuously and appears to indicate a close relationship to the palaeoenvironmental conditions and the associated Nereites ichnofacies, Zoophycos ichnofacies, and impoverished Zoophycos ichnofacies (Celis, 2016) (Fig. 3). The abundance of Phycosiphon is closely related to each of the ichnofacies. In general, the abundance of Phycosiphon is low when the Nereites ichnofacies is present and is high in the Zoophycos ichnofacies. This agrees with the usual composition of both ichnofacies; even Zoophycos is the typical ichnogenus in the Zoophycos ichnofacies, in some cases Phycosiphon can be the dominant ichnogenus (Frey \& Pemberton, 1984; Buatois \& Mángano, 2011). In the Nereites ichnofacies, Phycosiphon also occurs, but not as dominant ichnotaxon. Within the upper part of the section, above $492 \mathrm{~m}$, where the impoverished Zoophycos ichnofacies is present, the abundance of Phycosiphon increases, showing the highest values throughout the entire section.

The occurrence of Phycosiphon shows an apparent relation to the general trend of the total organic carbon content. In the upper part of the section where the abundance of Phycosiphon increases (492-685 m), the average TOC values increase too (Fig. 3). In addition, the greatest abundance of Phycosiphon occurring along the section (237-267 m, 492-552 m, and 635-648 m) coincides with increasing TOC values (Fig. 3). With respect to the rest of observed ichnological features (diameter, distribution, and abundance of Phycosiphon traces), the high abundance of Phycosiphon associated with high TOC values is also accompanied by the dominance of this trace within the beds.
Moreover, large specimens are mainly located in the upper part of the section, where the average of TOC values is high.

Abundance, size and distribution of Phycosiphon are narrowly related with organic matter content, as coherent with previous works showing that Phycosiphon is frequently associated with food availability (Ekdale \& Masson, 1988; Wetzel \& Uchman, 2001; Hovikoski et al., 2008; Pervesler \& Uchman, 2007; Wetzel, 2010; Rodríguez-Tovar et al., 2014). In the studied case, this interpretation supports previous findings suggesting increasing productivity in oceanic waters and resultant eutrophication towards the top of the section (Plata et al., 2018). Concomitantly, also the number/thickness of sandstone beds and terrigenous material, and fossil remains increase. An upper slope environment is interpreted being influenced by channels that drag the material within hyperpycnal flows (Celis, 2016), according to the characteristics proposed for this mechanism by Zavala \& Pan (2018).

\section{CONCLUSIONS}

The mudrocks from Ladrilleros-Juanchaco section (Miocene, Colombia Pacific), are characterized by a diverse trace fossil assemblage. Phycosiphon occurs throughout the entire section. Dense aggregations of Phycosiphon having variable size are present in different arrangements, in patches, or occupying beds partly or completely. Likewise, the relative abundance of Phycosiphon shows a close relationship with the encountered ichnofacies; Phycosiphon abundance decreases in the Nereites ichnofacies and increases in the Zoophycos ichnofacies. Within the impoverished Zoophycos ichnofacies, in the upper part of the studied section the highest abundance of Phycosiphon was found. In general, larger specimens and higher abundance of Phycosiphon, and the dominant presence within beds correlates with high TOC values. This supports the relationship between burrow size and food availability. In combination, ichnological, sedimentological and geochemical data from the Ladrilleros-Juanchaco section reveal high productivity conditions during times when the upper part of the section accumulated, as well as episodically in the lower part.

\section{ACKNOWLEDGEMENTS}

We would like to thank the technical and scientific staff of Instituto de Investigaciones en Estratigrafía-IIES (Universidad de Caldas) for the economic and logistic support. Thankful with the Colombian Association of Petroleum Geologist and Geophysicists (ACGGP) and 
the Corporación Geológica ARES, Bogotá, for providing economic support through the ARES-Corrigan. We also thank Agustin Cardona and Universidad Nacional de Colombia - Medellín for assisting and providing economic support in the preparation of TOC samples. Funding for research of RT was provided by Project CGL2015-66835-P (Secretaría de Estado de I+D+I, Spain), Research Group RNM-178 (Junta de Andalucía), and Scientific Excellence Unit UCE-2016-05 (Universidad de Granada). We are grateful to Gonzalo Jiménez Moreno for his editorial work, and to Andreas Wetzel, and one anonymous reviewer for their diligent review and comments.

\section{REFERENCES}

ANH-U Caldas. 2011. Estudio geológico integrado en la Cuenca Tumaco Onshore. Síntesis cartográfica, sísmica y análisis bioestratigráfico, petrográfico, geocronológico, termocronológico y geoquímico de testigos de perforación y muestras de superficie. Informe contrato 092 (unpublished), 191.

Barrero, D., Pardo, A., Vargas, C. \& Martínez, A. 2007. Colombian Sedimentary Basins: Nomenclature, Boundaries and Petroleum Geology, a New Proposal. (ANH and B\&M Exploration Ltda ed. Vol. 1). Agencia Nacional de Hidrocarburos, Bogotá, 1-92.

Bayet-Goll, A., Neto de Carvalho, C., Mahmudy-Gharaei, M.H. \& Nadaf, R. 2015. Ichnology and sedimentology of a shallow marine Upper Cretaceous depositional system (Neyzar Formation, Kopet-Dagh, Iran): palaeoceanographic influence on ichnodiversity. Cretaceous Reaserch, 56, 628646; doi: 10.1016/j.cretres.2015.07.008.

Bayet-Goll, A., Monaco, P., Jalili, F. \& Hossein-Mohammad, M.G. 2016. Depositional environments and ichnology of Upper Cretaceous deep-marine deposits in the Sistan Suture Zone, Birjand, Eastern Iran. Cretaceous Research, 60, 28-51; doi: 10.1016/j.cretres.2015.10.015.

Bednarz, M. \& McIlroy, D. 2009. Three-dimensional reconstruction of "phycosiphoniform" burrows: implications for identification of trace fossil in core. Palaeontologia Electronica, 12, 12.3.13A.

Bedoya, G., Cediel, F., Restrepo-Correa, I., Cuartas, C., Montenegro, G., Marín-Cerón, M.I., Mojica, J. \& Cerón, R. 2009. Aportes al conocimiento de la evolución geológica de las cuencas Atrato y San Juan dentro del arco Panamá-Chocó. Boletín de Geología UIS, 31, 69-81.

BGR - Ingeominas. 1989. Mineralizaciones Primarias de Minerales del Grupo del Platino y Oro en las Cuencas de los Ríos Condoto e Iró. Chocó, Colombia.

Bromley, R.G. 1996. Trace Fossils. Biology, Taphonomy and Applications. Chapman and Hall, Londres.

Buatois, L.A. \& Lopez-Angriman, A.O. 1992. Icnología de la Formación Wisky Bay (Cretácico, Isla James Ross, Antártida): Implicaciones paleoecológicas y paleoambientales. Ameghiniana, 28, 75-88.
Buatois, L.A. \& Mángano, M.G. 2011. Ichnology: OrganismSubstrate Interactions in Space and Time. Cambridge University Press, Cambridge.

Buatois, L.A., Saccavino, L.L. \& Zavala, C. 2011. Ichnologic signatures of hyperpycnal-flow deposits in Cretaceous river-dominated deltas, Austral Basin, southern Argentina. American Association of Petroleum Geologists, Studies in Geology, 61, 1-18; doi: 10.1306/13271355St611948.

Callow, R.H.T., Kneller, B., Dykstra, M. \& Mcllroy, D. 2014. Physical, biological, geochemical and sedimentological controls on the ichnology of submarine canyon and slope channel systems. Marine and Petroleum Geology, 54, 144-166; doi: 10.1016/j.marpetgeo.2014.02.016.

Cediel, F., Restrepo, I., Marín-Cerón, M.I., Duque-Caro, H., Cuartas, C., Mora, C., Montenegro, G., García, E., Tovar, D. \& Muñoz, G. 2010. Geology and Hydrocarbon Potential, Atrato and San Juan Basins, Chocó (Panamá) Arc. Colombia Tumaco Basin (Pacific Realm). ANH. Medellín.

Celis, S.A. 2016. Reconstrucción paleoambiental de la secuencia Mioceno Ladrilleros - Juanchaco: una contribución a la paleoceanografía del Pacífico Oriental Tropical. M.Sc. Thesis. Universidad de Caldas, Manizales, Colombia, 134.

Coates, A.G., Collins, L.S., Aury, M.-P. \& Berggren, W.A. 2004. The geology of the Darien, Panama, and the late Miocene-Pliocene collision of the Panama arc with northwestern South America. Geological Society Association Bulletin, 116, 1327-1344; doi: 10.1130/ B25275.1.

Correa, L.E. 2015. Estudio palinoestratigráfico de la sección Ladrilleros-Juanchaco (Cuenca San Juan), Pacífico colombiano. M.Sc. Thesis. Centro de Investigación Científica y de Educación Superior de Ensenada, Baja California. Ensenada, México, 103.

Dorador, J. \& Rodríguez-Tovar, F.J. 2014a. IODP Expedition 339 Scientists. Digital image treatment applied to ichnological analysis of marine core sediments. Facies, 60, 39-44; doi: 10.1007/s10347-013-0383-z.

Dorador, J. \& Rodríguez-Tovar, F.J. 2014b. IODP Expedition 339 Scientists. Quantitative estimation of bioturbation based on digital image analysis. Marine Geology, 349, 55-60; doi: 10.1016/j.margeo.2014.01.003.

Dorador, J. \& Rodríguez-Tovar, F.J. 2018. High-resolution image treatment in ichnological core analysis: Initial steps, advances and prospects. Earth-Science Reviews, 177, 226237; doi: 10.1016/j.earscirev.2017.11.020.

Dunia Consultores Ltda. 2006. Cartografía Geológica en el Área de la Cuenca Atrato-San Juan, Departamento del Chocó. Informe final. 180.

Duque-Herrera, A.F., Helenes, J., Pardo-Trujillo, A., Florez, J.A. \& Sierro, F.J. 2018. Miocene biostratigraphy and paleoecology from dinoflagellates, benthic foraminifera and calcareous nannofossils on the Colombian Pacific coast. Marine Micropaleontology, 141, 42-54; doi: 10.1016/j.marmicro.2018.05.002.

Duque-Caro, H. 1990a. Neogene stratigraphy, paleoceanography and paleobiogeography in northwest 
South America and the evolution of the Panama seaway. Palaeogeography, Palaeoclimatology, Palaeoecology, 77, 203-234; doi: 10.1016/0031-0182(90)90178-A.

Duque-Caro, H. 1990b. The Choco block in the northwestern corner of South America: Structural, tectonostratigraphic, and paleogeographic implications. Journal of South American Earth Sciences, 3, 71-84; doi: 10.1016/08959811(90)90019-W.

Duque-Caro, H. 1991. Contributions to the geology of the Pacific and Caribbean coastal áreas of northwestern Colombia and South America. Ph.D. Thesis. Princeton University, Nueva Jersey, Estados Unidos. 132.

Echeverri, S., Cardona, A., Pardo, A., Monsalve, G., Valencia, V.A., Borrero, C., Rosero, S. \& López, S. 2015. Regional provenance from southwestern Colombia fore-arc and intra-arc basins: implications for Middle to Late Miocene orogeny in the Northern Andes. Terra Nova, 27, 356-363; doi: $10.1111 /$ ter.12167.

Ekdale, A.A. \& Lewis, D.W. 1991. Trace fossils and paleoenvironmental control of ichnofacies in a late Quaternary gravel and loess fan delta complex, New Zealand. Palaeogeography, Palaeoclimatology, Palaeoecology, 81, 253-279; doi: 10.1016/00310182(91)90150-P.

Ekdale, A.A. \& Mason, T.R. 1988. Characteristic tracefossil associations in oxygen-poor sedimentary environments. Geology, 16, 720-723; doi: 10.1130/0091-7613(1988)016<0720:CTFAIO >2.3.CO;2.

Farris, D.W., Jaramillo, C., Bayona, G., Restrepo-Moreno, S.A., Montes, C., Cardona, A., Mora, A., Speakman, R.J., Glascock, M.D. \& Valencia, V. 2011. Fracturing of the Panamanian Isthmus during initial collision with South America. Geology, 39, 1007-1010; doi: 10.1130/G32237.1.

Figueroa, Y. \& Nuñez, A. 1990. Cartografía geológica de un área en las cabeceras del río San Juan (Chocó). B.Sc. Thesis. Universidad Nacional de Colombia. Bogotá, Colombia. 61.

Frey, R.W. \& Pemberton, S.G. 1984. Trace fossils facies models. In: Facies Models (ed. Walker, R.G.). Geoscience Canada Reprint Series, 189-207.

Fu, S. 1991. Funktion, Verhalten und Einteilung fucoider und lophoctenoider Lebensspuren. (Function, behavior and classification of fucoides and lophoctenoides traces). Courier Forschungsinstitut Senckenberg, 135, 1-79.

Gallego, N.F. 2017. Análisis de procedencia de las unidades Paleógenas en la Cuenca San Juan (Pacífico colombiano), y su relación con la paleogeografía de la esquina $\mathrm{NW}$ de Suramérica. M.Sc. Thesis. Universidad de Caldas, Manizales, Colombia. 99.

Garzón, D.M. 2017. Condiciones paleoceanográficas profundas durante el Serravaliano (Mioceno medio) en el Pacífico colombiano, Secuencia Sedimentaria Ladrilleros-Juanchaco. B.Sc. Thesis. Universidad de Caldas, Manizales, Colombia. 117.

Goldring, R., Pollard, J.E. \& Taylor, A.M. 1991. Anconichnus horizontalis: a pervasive ichnofabric-forming trace fossil in post-Paleozoic offshore siliciclastic facies. Palaios, 6, 250-263; doi: 10.2307/3514905.
Hernández-Rendón, E. 2015. Estudio sedimentológico y de nanofósiles calcáreos del intervalo 13,294-11,863 Ma (Serravaliense) en la secuencia Ladrilleros-Juanchaco, (Pacífico Ecuatorial Oriental, Colombia). B.Sc. Thesis. Universidad de Caldas. Manizales, Colombia. 90.

Hovikoski, J., Lemiski, R., Gingras, M., Pemberton, G. \& MacEachern, J.A. 2008. Ichnology and sedimentology of a mud-dominated deltaic coast: Upper Cretaceous Alderson Member (Lea Park Fm), western Canada. Journal of Sedimentary Research, 78, 803-824; doi: 10.2110/jsr.2008.089.

Knaust, D. \& Bromley, R.G. 2012. Trace Fossils as Indicators of Sedimentary Environments. Developments in Sedimentology, 64. Elsevier, Amsterdam.

Monaco, P., Rodríguez-Tovar, F. \& Uchman, A. 2012. Ichnological analysis of lateral environmental heterogeneity within the Bonarelli level (uppermost Cenomanian) in the classical localities near Gubbio, Central Apennines, Italy. Palaios, 27, 48-54; doi: 10.2110/palo.2011.p11-018r.

Montes, C., Cardona, A., McFadden, R., Morón, S.E., Silva, C.A., Restrepo-Moreno, S., Ramírez, D.A., Hoyos, N., Wilson, J., Farris, D., Bayona, G.A., Jaramillo, C.A., Valencia, V., Bryan, J. \& Flores, J.A. 2012. Evidence for Middle Eocene and younger land emergence in Central Panama: Implications for Isthmus Closure. Geological Society of America Bulletin, 124, 780-799; doi: 10.1130/ B30528.1.

Montes, C., Cardona, A., Jaramillo, C., Pardo, A., Silva, J.C., Valencia, V., Ayala, C., Pérez-Angel, L.C., RodriguezParra, L.A., Ramirez, V. \& Niño, H. 2015. Middle Miocene closure of the Central American seaway. Science, 348, 226-229; doi: 10.1126/science.aaa2815.

Montoya, D.M. 2003. Geología de las Planchas 240 Pichimá, 241 Cucurrupí, 259 Malaguita y 260 Aguas Claras. Departamentos de Chocó y Valle del Cauca. Escala 1. 200000. Memoria Explicativa. Ingeominas, 1-91.

Netto, R.G. \& Rossetti, D.F. 2003. Ichnology and salinity fluctuations: a case study from the Early Miocene (lower Barreiras Formation) of São Luís Basin, Maranhão Brazil. Revista Brasilera de Paleontología, 6, 5-18.

Netto, R.G., Balistieri, P.R.M.N., Lavina, E.L.C. \& Silveira, D.M. 2009. Ichnological signatures of shallow freshwater lakes in the glacial Itararé group (Mafra Formation, upper Carboniferous-Lower Permian of Paraná Basin, S Brazil). Palaeogeography, Palaeoclimatology, Palaeoecology, 272, 240-255; doi: 10.1016/j.palaeo.2008.10.028.

Pervesler, P. \& Uchman, A. 2007. Ichnology of the Lower Badenian (Middle Miocene) Baden-Sooß core at the type locality of the Badenian (Vienna Basin, Lower Austria). Joannea Geologie und Paläontologie, 9, 79-81.

Plata, A. 2012. Diatomeas del Pacifico ecuatorial colombiano; aportes a la bioestratigrafía y análisis paleoambiental de sedimentos de la Secuencia Ladrilleros, sector LadrillerosJuanchaco, "Valle del Cauca-Colombia". M.Sc. Thesis. Universidad de Salamanca. Salamanca, España, 63.

Plata, A., Bárcena, M.A., Vallejo, D.F., Trejos, R., PardoTrujillo, A., Flores, J.A. \& Sierro, F.J. 2018. First record of middle Miocene marine diatoms from the Colombian 
Pacific (NW South America) and their paleoceanographic significance. Marine Micropaleontology, 140, 17-32; doi: 10.1016/j.marmicro.2017.12.005.

Rodríguez-Tovar, F.J. \& Dorador, J. 2015. Ichnofabric characterization in cores: a method of digital image treatment. Annales Societatis Geologorum Poloniae, 85, 465-471; doi: 10.14241/asgp.2015.010.

Rodríguez-Tovar, F.J. \& Uchman, A. 2004a. Trace fossils after the K-T boundary event from the Agost section, SE Spain. Geological Magazine, 141, 429-440; doi: 10.1017/ S0016756804009410.

Rodríguez-Tovar, F.J. \& Uchman, A. 2004b. Ichnotaxonomic analysis of the Cretaceous/Palaeogene boundary interval in the Agost section, south-east Spain. Cretaceous Research, 25, 635-647; doi: 10.1016/j.cretres.2004.06.003.

Rodríguez-Tovar, F.J. \& Uchman, A. 2006. Ichnological analysis of the Cretaceous-Palaeogene boundary interval at the Caravaca section, SE Spain. Palaeogeography, Palaeoclimatology, Palaeoecology, 242, 313-325; doi: 10.1016/j.palaeo.2006.06.006.

Rodríguez-Tovar, F.J. \& Uchman, A. 2010. Ichnofabric evidence for the lack of bottom anoxia during the lower Toarcian Oceanic Anoxic Event in the Fuente de la Vidriera section, Betic Cordillera, Spain. Palaios, 25, 576-587; doi: 10.2110/palo.2009.p09-153r.

Rodríguez-Tovar, F.J. \& Uchman, A. 2017. The Faraoni event (latest Hauterivian) in ichnological record: The Río Argos section of southern Spain. Cretaceous Research, 79, 109121; doi: 10.1016/j.cretres.2017.07.018.

Rodríguez-Tovar, F.J., Uchman, A. \& Martín-Algarra, A. 2009a. Oceanic anoxic event at the CenomanianTuronian boundary interval (OAE-2): ichnological approach from the Betic Cordillera, southern Spain. Lethaia, 42, 407-417; doi: 10.1111/j.1502-3931.2009.00159.x.

Rodríguez-Tovar, F.J., Uchman, A., Martín-Algarra, A. \& O’Dogherty, L. 2009b. Nutrient spatial variation during intrabasinal upwelling at the Cenomanian-Turonian oceanic anoxic event in the westernmost Tethys: an ichnological and facies approach. Sedimentary Geology, 215, 83-93; doi: 10.1016/j.sedgeo.2009.01.006.

Rodríguez-Tovar, F.J., Uchman, A., Alegret, L. \& Molina, E. 2011a. Impact of the Paleocene-Eocene Thermal Maximum on the macrobenthic community: ichnological record from the Zumaia section, northern Spain. Marine Geology, 282, 178-187; doi: 10.1016/j.margeo.2011.02.009.

Rodríguez-Tovar, F.J., Uchman, A., Orue-Etxebarria, X., Apellaniz, E. \& Baceta, J.I. 2011b. Ichnological analysis of the Bidart and Sopelana Cretaceous/Paleogene (K/ $\mathrm{Pg}$ ) sections (Basque Basin, W Pyrenees): refining ecosedimentary environment. Sedimentary Geology, 234, 42-55; doi: 10.1016/j.sedgeo.2010.11.004.

Rodríguez-Tovar, F.J., Uchman, A., Orue-Etxebarria, X. \& Apellaniz, E.I. 2013. Palaeoenvironmental changes during the Danian-Selandian boundary interval: the ichnological record at the Sopelana section (Basque Basin, W Pyrenees). Sedimentary Geology, 284-285, 106-116; doi: 10.1016/j.sedgeo.2012.11.009.
Rodríguez-Tovar, F.J, Nagy, J. \& Reolid, M. 2014. Palaeoenvironment of Eocene prodelta in Spitsbergen recorded by the trace fossil Phycosiphon incertum. Polar Research, 33, 23786; doi: 10.3402/polar.v33.23786.

Rodríguez-Tovar, F.J., Piñuela, L. \& García-Ramos, J.C. 2016. Trace fossils assemblages from the Cenozoic "Flysch Units" of the Campo de Gibraltar Complex (Southern Spain). Ichnos, 23, 53-70; doi: 10.1080/10420940.2015.1130708.

Rojas, O. 1967. Geological Traverses in the Chocó Region. Northwestern Colombia.

Seilacher, 2007. Trace Fossil Analysis. Springer Science \& Business Media.

Spikings, R.A., Winkler, W., Seward, D. \& Handler, R. 2001. Along-strike variations in the thermal and tectonic response of the continental Ecuadorian Andes to the collision with heterogeneous oceanic crust. Earth and Planetary Science Letters, 186, 57-73; doi: 10.1016/ S0012-821X(01)00225-4.

Spikings, R.A., Crowhurst, P.V., Winkler, W. \& Villagomez, D. 2010. Syn- and post-accretionary cooling history of the Ecuadorian Andes constrained by their in-situ and detrital thermochronometric record. Journal of South American Earth Sciences, 30, 121-133; doi: 10.1016/j. jsames.2010.04.002.

Suárez-Rodríguez, M. 2007. Geological framework of the Pacific coast sedimentary basins. Geología Colombiana, 32, 47-62.

Taylor, A.M. \& Goldring, R. 1993. Description and analysis of bioturbation and ichnofabric. Journal of the Geological Society, London, 150, 141-148; doi: 10.1144/ gsjgs.150.1.0141.

Trejos, R.A. 2012. Análisis bioestratigráfico y paleoecológico basado en el estudio de foraminiferos planctónicos de la sección estratigráfica de Ladrilleros-Juanchaco; costa Pacifica de Colombia. M.Sc. Thesis. Universidad de Salamanca. Salamanca, España. 72.

Uchman, A. 1991. Trace fossils from stress environments in Cretaceous-Paleogene flysch of the Polish Outer Carpathians. Annales Societatis Geologorum, 61, 207-220.

Uchman, A. 1992. An opportunistic trace fossil assemblage from the flysch of the Inoceramian beds (CampanianPaleocene), Bystrica Zone of the Magura Nappe, Carpathians, Poland. Cretaceous Research, 13, 539-547; doi: 10.1016/0195-6671(92)90016-J.

Uchman, A. 1995. Taxonomy and paleoecology of flysch trace fossils: The Marnoso-Arenacea Formation and associated facies (Northern Apennines, Italy). Beringeria, 15, 1-115.

Uchman, A. 1998. Taxonomy and ethology of flysch trace fossils: revision of the Marian Książkiewicz collection and studies of complementary material. Annales Societatis Geologorum Poloniae, 68, 105-218.

Uchman, A. 1999. Ichnology of the Rhenodanubian Flysch (Lower Cretaceous-Eocene) in Austria and Germany. Beringeria, 25, 67-173.

Uchman, A. \& Wetzel, A. 2012. Deep-sea fans. In: Trace Fossils as Indicators of Sedimentary Environments (eds Knaust, D. \& Bromley, R.G.). Developments in Sedimentology, 64, 643-672. 
Vallejo, D.F. 2012. Análisis bioestratigráfico y paleoambiental por medio de nanofósiles calcáreos en la "Secuencia Ladrilleros-Juanchaco", NW de Suramérica-Colombia. M.Sc. Thesis. Universidad de Salamanca. Salamanca, España. 92.

Vallejo, D.F., Flores, J.A., Plata, A., Trejos, R., PardoTrujillo, A., Sierro, F.J. \& Bárcena, M.A. 2016. LowLatitude Miocene calcareous and siliceous microfossil biostratigraphy from South America: LadrillerosJuanchaco section (Colombian Pacific). Ameghiniana, 53, 629-644; doi: 10.5710/AMGH.11.08.2016.2978.

Villagómez, D. \& Spikings, R. 2013. Thermochronology and tectonics of the Central and Western Cordilleras of Colombia: Early Cretaceous-Tertiary evolution of the Northern Andes. Lithos, 160-161, 228-249; doi: 10.1016/j. lithos.2012.12.008.

Villagómez, D., Spikings, R., Magna, T., Kammer, A., Winkler, W. \& Beltrán, A. 2011. Geochronology, geochemistry and tectonic evolution of the Western and Central cordilleras of Colombia. Lithos, 125, 875-896; doi: 10.1016/j.lithos.2011.05.003.

Wetzel, A. 2008. Recent bioturbation in the deep South China Sea: a uniformitarian ichnologic approach. Palaios, 23, 601-615; doi: 10.2110/palo.2007.p07-096r.
Wetzel, A. 2010. Deep-sea ichnology: observations in modern sediments to interpret fossil counterparts. Acta Geologica Polonica, 60, 125-138.

Wetzel, A. \& Balson, P. 1992. Sedimentology of fine-grained turbidites inferred from continuously recorded physical properties data. Marine Geology, 104, 165-178; doi: 10.1016/0025-3227(92)90091-U.

Wetzel, A. \& Bromley, R.G. 1994. Phycosiphon incertum revisited: Anconichnus horizontalis is its junior subjective synonym. Journal of Paleontology, 68, 1396-1402; doi: 10.1017/S0022336000034363.

Wetzel, A. \& Uchman, A. 2001. Sequential colonization of muddy turbidites in the Eocene Beloveža Formation, Carpathians, Poland. Paleogeography, Palaeoclimatology, Palaeoecology, 168, 171-186; doi: 10.1016/S00310182(00)00254-6.

Wetzel, A. \& Uchman, A. 2012. Hemipelagic and pelagic basin plains. In: Trace Fossils as Indicators of Sedimentary Environments (eds Knaust, D. \& Bromley, R.G.). Developments in Sedimentology, 64, 673-702.

Zavala, C. \& Pan, S.X. 2018. Hyperpycnal flows and hyperpycnites: Origin and distinctive characteristics. Lithologic Reservoirs, 30, 1-27; doi: 10.3969/j.issn.16738926.2018.01.001. 
